PEMBERIAN TEPUNG DAUN MENGKUDU (Morinda citrifolia Linn) SEBAGAI SUPPLEMENT PADA RANSUM BROILER

\author{
LAPORAN
}

PROYEK USAHA MANDIRI

OLEH:

BADRIS SHODA

NIM. 16253231035

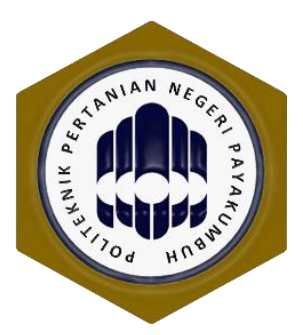

PROGRAM STUDI BUDI DAYA TERNAK JURUSAN BUDIDAYA TANAMAN PANGAN

POLITEKNIK PERTANIAN NEGERI PAYAKUMBUH PAYAKUMBUH 2019 


\title{
PEMBERIAN TEPUNG DAUN MENGKUDU (Morinda citrifolia Linn) SEBAGAI SUPPLEMENT PADA RANSUM BROILER
}

Oleh :

\author{
BADRIS SHODA \\ 16253231035
}

\section{RINGKASAN}

Penyediaan pakan yang memadai dalam peternakan unggas sangat menunjang keberhasilan usaha. Pakan merupakan semua bahan yang dapat dimakan ternak, dicerna, diserap dan juga dapat dipergunakan untuk memenuhi kebutuhannya. Untuk meningkatkan pertumbuhan broiler banyak peternak percaya bahwa produksi ternak hampir tidak mungkin berhasil tanpa penggunaan antibiotik sebagai pemacu pertumbuhan (Antibiotic Growth Promotor). Adanya dampak negatif dan dilarangnya penggunaan AGP, pakan yang ada sekarang tidak bisa menunjang pertumbuhan broiler sesuai dengan potensinya, maka dicarilah alternatif lain yang berbahan dasar organik salah satunya menggunakan supplement pada daun mengkudu.

Kegiatan Proyek Usaha Mandiri dilaksanakan di kandang broiler UPT Farm Politeknik Pertanian Negeri Payakumbuh pada tanggal 26 Februari 2019 sampai tanggal 14 Mei 2019. Alat yang digunakan dalam pelaksanaan pemeliharaan ayam tersebut adalah tempat pakan, tempat minum, piting lampu, bola lampu, ember, tirai plastik, timbangan, kabel, kuas, sapi lidi, pisau, colokan dan ember. Bahan yang digunakan adalah DOC, BR-1, koran, kapur, sekam padi, vaksin ND, gula, kantong plastik, tali raffia dan tepung daun mengkudu.

Pertambahan bobot badan perlakuan lebih tinggi jika dibandingkan dengan pertambahan bobot badan kontrol selama 2 kali periode pemeliharaan, karena pakan yang dikonsumsi lebih tinggi. PBB perlakuan periode 1 sebesar $1.458 \mathrm{~g}$ dan periode 2 sebesar $1.444 \mathrm{~g}$. Sedangkan kontrol sebesar $1.372 \mathrm{~g}$ pada periode $1 \mathrm{dan}$ $1.329 \mathrm{~g}$ pada periode 2 . Konversi ransum perlakuan diperoleh 1,37 untuk periode 1 dan 1,36 untuk periode 2, sedangkan kontrol diperoleh 1,44 pada periode 1 dan 1,40 pada periode 2 .

Pertambahan bobot badan dan konsumsi perlakuan lebih tinggi jika dibandingkan dengan pertambahan bobot badan kontrol selama 2 kali periode pemeliharaan. 


\section{PENDAHULUAN}

\subsection{Latar Belakang}

Pertambahan jumlah penduduk pasti selalu diikuti dengan bertambahnya kebutuhan manusia, baik itu kebutuhan sandang (pakaian) maupun kebutuhan pangan (makanan). Kebutuhan pangan merupakan kebutuhan yang sangat penting. Salah satu kebutuhan tersebut adalah daging, baik itu daging kambing, sapi maupun ayam. Broiler merupakan sumber pangan hewani yang mudah didapat dengan harga yang relatif murah dibandingkan dengan ternak lainnya (seperti : sapi, kambing dan kerbau). Produksi broiler dapat dicapai dengan baik apabila didukung oleh bibit yang berkualitas, ransum yang baik dan manajemen pemeliharaan.

Beternak broiler merupakan usaha yang menjanjikan, karena perputaran modal sangat cepat dan broiler telah dikenal oleh masyarakat Indonesia dalam berbagai kelebihan, 4-5 minggu sudah bisa dipanen dengan waktu pemeliharaan yang relatif singkat dan menguntungkan. Broiler juga merupakan salah satu jenis ternak yang memiliki kemampuan yang tinggi dalam mengkonversikan ransum yang dikonsumsinya menjadi daging. Produktifitas broiler dipengaruhi oleh dua hal yaitu genetik dan lingkungan. Faktor lingkungan memberikan pengaruh yang besar dalam menentukan performa broiler yaitu sebesar (70\%) yang meliputi suhu, pakan dan manajemen pemeliharaan. Sedangkan faktor genetik hanya mempengaruhi sebesar (30\%).

Penyediaan pakan yang memadai dalam peternakan unggas sangat menunjang keberhasilan usaha. Pakan merupakan campuran dari berbagai macam bahan organik yang diberikan kepada ternak untuk memenuhi kebutuhan zat-zat makanan yang diperlukan bagi pertumbuhan, perkembangan dan reproduksi. Agar pertumbuhan dan produksi lebih maksimal, jumlah dan kandungan zat-zat makanan yang diperlukan ternak harus memadai (Suprijatna, 2008).

Zat gizi atau nutrisi tersebut bisa berupa sumber protein, karbohidrat, lemak, vitamin dan mineral dalam pakan yang dikonsumsinya atau yang dapat disintesis dalam tubuhnya sendiri. Pakan merupakan semua bahan yang dapat dimakan ternak, dicerna, diserap dan juga dapat dipergunakan untuk memenuhi 
kebutuhannya. Pertumbuhan yang cepat diikuti oleh menurunnya daya tahan tubuh broiler, untuk meningkatkan pertumbuhan broiler banyak peternak percaya bahwa produksi ternak hampir tidak mungkin berhasil tanpa penggunaan antibiotik sebagai pemacu pertumbuhan (Antibiotic Growth Promotor). Penggunaan Antibiotic Growth Promotor (AGP) menyebabkan penggunaan antibiotik sebagai pemacu pertumbuhan pada unggas telah dilarang di beberapa negara karena adanya cemaran dan residu yang berbahaya bagi konsumen (Fritts and Waldroup, 2003). Adanya dampak negatif dan dilarangnya penggunaan AGP, pakan yang ada sekarang tidak bisa menunjang pertumbuhan broiler sesuai dengan potensinya, maka dicarilah alternatif lain yang berbahan dasar organik salah satunya menggunakan supplement pada daun mengkudu.

Feed supplement merupakan zat tambahan yang memilki nutrisi, terutama nutrisi mikro seperti vitamin, mineral atau asam amino. Pemberian feed supplement dalam ransum berfungsi sebagai melengkapi atau meningkatkan ketersedian zat nutrisi. Feed supplement yang diberikan dalam ransum berupa feed supplement alami. Salah satu cara yang dapat dilakukan adalah pemanfaatan tanaman mengkudu (Morinda citrifolia linn).

Daun mengkudu dapat digunakan sebagai pakan karena tersedia setiap waktu, tidak bersaing dengan manusia, mengandung nutrisi lengkap dan tinggi seperti protein 21,63\% dan lemak 3,06\% (Mardiansyah, 2013). Menurut Sjabana dan Bahalwan (2000), daun dan buah mengkudu mengandung zat nutrisi seperti protein, vitamin serta mineral. Senyawa-senyawa yang berperan dalam mengkudu sangat aktif dalam menguatkan sistem kekebalan tubuh, memperbaiki fungsi sel dan mempercepat regenerasi sel-sel yang rusak seperti senyawa xeronin, proxeronin, proxeronase, serotonin, zat antikanker (damnacanthal), scopoletin, sumber vitamin $\mathrm{C}$, anti oksidan, mineral, protein, enzim, alkaloid dan fitronutrien lainnya yang (Djauhariya dan Tirtoboma, 2001). Sedangkan menurut Darusman (2002), pada daun mengkudu terkandung protein, zat kapur, zat besi, karoten dan askorbin.

Daun mengkudu juga mengandung xeronine yang dapat membantu penyerapan protein (Bangun dan Sarwono, 2002). Wardiny (2006), menyatakan bahwa tepung daun mengkudu mengandung protein kasar 22,11\%, Ca 10,30\%, Fe 
$437 \mathrm{ppm}, \mathrm{Zn}$ 35,80 ppm dan $\beta$-karoten $161 \mathrm{ppm}$. Pemberian tepung daun mengkudu (Morinda citrifolia linn) dengan taraf 2\% dapat meningkatkan pertambahan bobot badan karena pada daun mengkudu mengandung $\beta$-karoten, Fe, dan Zn yang membuat ayam lebih cepat tumbuh (Wardiny dan Sinar, 2011). Berdasarkan hal tersebut telah dilaksanakan Proyek Usaha Mandiri (PUM) yang berjudul "Pemberian Tepung Daun Mengkudu (Morinda citrifolia linn) Sebagai Supplement Pada Ransum Broiler".

\subsection{Tujuan}

Tujuan dari Proyek Usaha Mandiri (PUM) yang berjudul "Pemberian Tepung Daun Mengkudu (Morinda citrifolia linn) Sebagai Supplement Pada Ransum Broiler" adalah untuk:

1. Mengetahui manfaat pemberian tepung daun mengkudu (Morinda citrifolia linn) sebagai supplement dalam pakan terhadap pertambahan bobot badan.

2. Melatih diri dalam merencanakan, melaksanakan dan melaporkan suatu usaha broiler.

\subsection{Manfaat}

Manfaat dalam pelaksanaan PUM yang berjudul "Pemberian Tepung Daun Mengkudu (Morinda citrifolia linn) Sebagai Supplement Pada Ransum Broiler" adalah:

1. Tersedianya informasi kepada masyarakat tentang pemberian tepung daun mengkudu terhadap pertambahan bobot badan broiler.

2. Terciptanya kemauan untuk melaksanakan suatu usaha broiler. 


\section{TINJAUAN PUSTAKA}

\subsection{Broiler}

Menurut North dan Bell (1990), broiler merupakan galur ayam dari hasil rekayasa genetik yang memiliki karakteristik dengan ciri khas pertumbuhan cepat sebagai penghasil daging, masa panen pendek dan menghasilkan daging berserat lunak, serta dada lebih besar dan kulit yang licin. Sedangkan menurut Kartasudjana dan Suprijatna (2006), broiler merupakan ayam jantan atau ayam betina yang bisa dipanen pada umur $5-6$ minggu yang bertujuan sebagai penghasil daging. Broiler berasal dari jenis ayam unggulan impor yang telah dikembangbiakkan yang bertujuan sebagai produksi (Ruhyat dan Suprijatna, 2006).

Pada umumnya di Indonesia broiler dipasarkan setelah berumur 4-5 minggu dengan bobot badan berkisar antara 1-2 kg, waktu pertumbuhan yang relatif singkat menandakan broiler memiliki kualitas genetik untuk pertumbuhan yang baik. Rentannya broiler terhadap penyakit disebabkan oleh tingginya laju pertumbuhan (Yuwanta dan Tri, 2004). Untuk itu diperlukan manajemen yang baik dalam pemeliharaan agar broiler tidak rentan terhadap penyakit sehingga kualitas genetik lebih maksimal.

Jenis strain broiler yang banyak beredar di pasaran adalah : Super 77, Tegal 70, ISA, Kim Cross, Hyline, Vdet, Missouri, Hubbard, Shaver Starbro, Pilch, Yabro, Goto, Arbor Arcres, Tatum, Indian River, Hybro, Cornis, Brahma, Langshans, Hypeco Broiler, Ross, Marshall "m", Euribrid, A.A 70, Sussex, Bromo (Cahyono, 2002).

\subsection{Tepung Daun Mengkudu (Morinda citrifolia linn)}

Tanaman mengkudu (Morinda citrifloria linn) memiliki tinggi 4-8 m, batangnya berkayu, kulit kasar, percabangan monopodial, coklat kekuningkuningan. Daun mengkudu berbentuk tunggal, berwarna hijau seperti bulat telur, ujung dan pangkal nya runcing dengan panjang 10-40 cm, lebar 5-17 cm. Pertulangannya menyirip dan bertangkai pendek. Bunga majemuk berbentuk bongkol bertangkai, terletak diketiak daun. Buah berwarna hijau kekuningan, 
berdaging dengan panjang 5-10 $\mathrm{cm}$. Tanaman ini berakar tunggang berwarna coklat muda (Syamsuhidayat dan Hutapea, 1991).

Tanaman mengkudu (Morinda citrifloria linn) berasal dari daerah tropis salah satunya di Indonesia. Tanaman mengkudu memiliki kandungan nutrisi yang cukup lengkap seperti protein, vitamin dan mineral yang sangat bermanfaat bagi tubuh (Sjabana dan Bahalwan, 2000).

Menurut Djauhariya dan Tirtoboma (2001), Senyawa-senyawa yang berperan dalam mengkudu sangat aktif dalam menguatkan sistem kekebalan tubuh, memperbaiki fungsi sel dan mempercepat regenerasi sel-sel yang rusak seperti senyawa xeronin, proxeronin, proxeronase, serotonin, zat antikanker (damnacanthal), scopoletin, sumber vitamin C, anti oksidan, mineral, protein, enzim, alkaloid dan fitronutrien lainnya yang. Senyawa lain yang terkandung pada daun mengkudu seperti protein, zat kapur, zat besi, karoten dan askorbin (Darusman, 2002). Sedangkan menurut Aprianto dan Farid (2002), daun dan akar mengkudu berfungsi sebagai antiseptik, antibakteri, dan antikanker yang berfungsi untuk meningkatkan daya tahan tubuh karena adanya senyawa antrakuinon (damnacanthal). Lebih lanjut oleh Risna (2012), menyatakan bahwa senyawa alkaloid, saponin, flavonoid, terpenoid dan antrakuinon, serta polifenol merupakan kandungan kimia yang ada pada daun dan buah mengkudu. Senyawasenyawa terpenoid berfungsi untuk membantu dalam proses sintesis organik dan pemulihan sel-sel tubuh dan bersifat bakterial.

Wardiny (2006), menyatakan bahwa tepung daun mengkudu mengandung protein kasar 22,11\%, Ca 10,30\%, Fe 437 ppm, Zn 35,80 ppm dan $\beta$-karoten 161 ppm. Tepung daun mengkudu dapat membuat ayam lebih cepat dewasa kelamin, produksi telur meningkat, konversi ransum menurun, dan pertambahan bobot badan meningkat karena adanya kandungan $\beta$-karoten, Fe dan $\mathrm{Zn}$. Kandungan nutrisi tepung daun mengkudu dapat dilihat pada Tabel 1 . 
Tabel 1. Nutrisi tepung daun mengkudu.

\begin{tabular}{|c|c|}
\hline Nutrien & Jumlah \\
\hline Bahan kering $(\%)$ & 92,92 \\
\hline $\mathrm{Abu}(\%)$ & 9,72 \\
\hline Protein kasar (\%) & 21,63 \\
\hline Serat kasar (\%) & 29,38 \\
\hline Lemak kasar (\%) & 3,06 \\
\hline Beta-N (\%) & 29,13 \\
\hline $\mathrm{Ca}(\%)$ & 2,28 \\
\hline $\mathrm{P}(\%)$ & 0,28 \\
\hline Energi bruto (Kal/g) & $4.147,00$ \\
\hline
\end{tabular}

Sumber : Laboratorium Ilmu dan Teknologi Pakan, Fakultas Peternakan, Institut Pertanian Bogor (2012).

Menurut Wardiny dan Sinar (2011), pemberian tepung daun mengkudu (Morinda citrifolia linn) dengan taraf 2\% dapat meningkatkan pertambahan bobot badan karena pada daun mengkudu mengandung $\beta$-karoten, Fe, dan $\mathrm{Zn}$ yang membuat ayam cepat tumbuh.

\subsection{Ransum Broiler}

Ransum merupakan campuran berbagai macam bahan organik dan anorganik yang dapat memenuhi kebutuhan zat-zat makanan yang diperlukan bagi pertumbuhan, perkembangan dan reproduksi (Suprijatna, 2008). Sedangkan menurut Sofyan (2008), ransum sangat berpengaruh dalam menentukan produksi ternak ayam pedaging (konsumsi, pertambahan bobot badan, konversi, angka mortalitas dan income over feed cost). Pakan broiler yang digunakan berasal dari pakan asal tumbuh tumbuhan, hewan, hasil ikutan dan sisa proses pabrik dan limbah industri (Murtidjo, 1987). Kebutuhan nutrisi pada pakan broiler dapat dilihat pada Tabel 2 . 
Tabel 2. Kebutuhan nutrisi pakan broiler pada periode starter dan periode finisher.

\begin{tabular}{clcc}
\hline No & \multicolumn{1}{c}{ Nutrisi } & Starter (1-21 hari) & Finisher (22-42 hari) \\
\hline 1 & Energi metabolis (kkal/kg) & 3200 & 3200 \\
2 & Protein kasar (\%) & 23,00 & 20,00 \\
3 & Serat kasar (\%) & 4,00 & 5,00 \\
4 & Lemak (\%) & 6,00 & 6,00 \\
5 & Ca(\%) & 1,00 & 0,90 \\
6 & P tersedia (\%) & 0,45 & 0,35 \\
7 & Lissin (\%) & 1,10 & 1,0 \\
8 & Metionin $(\%)$ & 0,50 & 0,38
\end{tabular}

Sumber: NRC (1994). 


\section{LANDASAN USAHA}

\subsection{Potensi Permintaan}

Potensi Permintaan diperoleh dari data produksi daging broiler dan ditambah dari edible offal (bagian yang dapat dimakan) yang didapatkan dari jumlah pemotongan broiler di Provinsi Sumatera Barat tahun 2014 - 2018 (Data Statistik Peternakan dan Kesehatan Hewan 2018), seperti pada Tabel 3.

Tabel 3. Jumlah pemotongan broiler di Provinsi Sumatera Barat 2014 - 2018.

\begin{tabular}{ccc}
\hline Tahun & Pemotongan broiler (ekor) & Karkas + edible offal* \\
\hline 2014 & 19.493 .000 & 19.103 .140 \\
2015 & 20.063 .000 & 19.661 .740 \\
2016 & 20.438 .000 & 20.029 .240 \\
2017 & 28.533 .000 & 27.962 .340 \\
$2018 * *$ & 28.521 .000 & 27.950 .580
\end{tabular}

Sumber : Dirjen Peternakan dan Kesehatan Hewan RI (2018).

Produksi daging : Karkas hasil pemotongan ternak di wilayah Provinsi Sumatera Barat Ket *: Diasumsikan bobot broiler 1.400 gram dengan karkas ditambah edible offal $70 \%$.

**: Data sementara.

Berdasarkan jumlah pemotongan broiler di Provinsi Sumatera Barat tahun 2014-2018 di atas, maka dapat dilihat pada Grafik 1 di bawah ini.

\section{Jumlah pemotongan broiler di Provinsi Sumatera Barat}

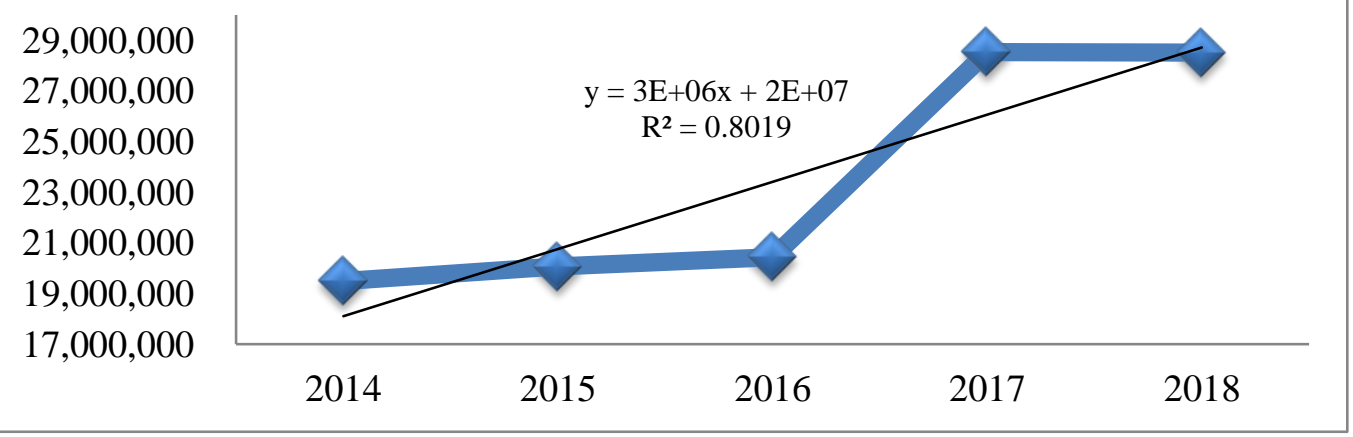

Gambar 1. Grafik pemotongan broiler di Provinsi Sumatera Barat tahun 2014-2018. 
Tabel 3 menunjukkan jumlah pemotongan broiler di Provinsi Sumatera Barat dari tahun 2014-2018 mengalami peningkatan setiap tahunnya. Berdasarkan data pemotongan broiler tahun 2014-2018, maka dapat diproyeksikan jumlah permintaan karkas broiler dari tahun 2020-2024 dengan menggunakan persamaan linear $\mathrm{Y}=\mathrm{a}+\mathrm{bX}$ atau $\mathrm{Y}=22.941 .408+2.599 .548 \mathrm{X}$ dan proyeksi permintaan karkas broiler pada tahun 2019 sebesar $30.740 .052 \mathrm{~kg}$. Berdasarkan persamaan linear tersebut maka dapat diproyeksikan berapa jumlah permintaan karkas broiler di Provinsi Sumatera Barat tahun 2020-2024 seperti yang terdapat pada Tabel 4.

Tabel 4. Proyeksi jumlah permintaan karkas broiler di Provinsi Sumatera Barat 2020-2024.

\begin{tabular}{cc}
\hline Tahun & Permintaan karkas broiler + edible offal $(\mathbf{k g})$ \\
\hline 2020 & 33.339 .600 \\
2021 & 35.939 .148 \\
2022 & 38.538 .696 \\
2023 & 41.138 .244 \\
2024 & 43.737 .792
\end{tabular}

Ket : Menggunakan rumus persamaan regresi linear $(\mathrm{Y}=\mathrm{a}+\mathrm{bX})$.

Dilihat dari Tabel 4 proyeksi permintaan karkas broiler di Provinsi Sumatera Barat terus mengalami peningkatan dari tahun ke tahun. Berarti permintaan broiler akan terus meningkat setiap tahunnya.

\subsection{Potensi Penawaran}

Potensi penawaran didapatkan dari jumlah populasi broiler yang ada di Provinsi Sumatera Barat untuk tahun 2014-2018 (Statistik Peternakan dan Kesehatan Hewan 2018), seperti pada Tabel 5. 
Tabel 5. Jumlah penawaran karkas broiler di Provinsi Sumatera Barat tahun 2014-2018.

\begin{tabular}{ccc}
\hline Tahun & Populasi broiler (ekor) & Karkas $(\mathbf{k g})^{*}$ \\
\hline 2014 & 17.921 .143 & 17.562 .720 \\
2015 & 18.445 .762 & 18.076 .847 \\
2016 & 18.790 .036 & 18.414 .235 \\
2017 & 26.232 .909 & 25.708 .251 \\
$2018^{* *}$ & 26.221 .529 & 25.697 .098 \\
\hline
\end{tabular}

Sumber : Dirjen Peternakan dan Kesehatan Hewan Kementrian Pertanian (2018)

Ket :* Hasil perhitungan dengan bobot hidup $=1,4 \mathrm{~kg} / \mathrm{ekor}$, dengan karkas ditambah edible offal $70 \%$.

*Data sementara.

Berdasarkan data tabel di atas, maka dapat dilihat pada grafik Jumlah penawaran karkas broiler di Provinsi Sumatera Barat pada Grafik 2.

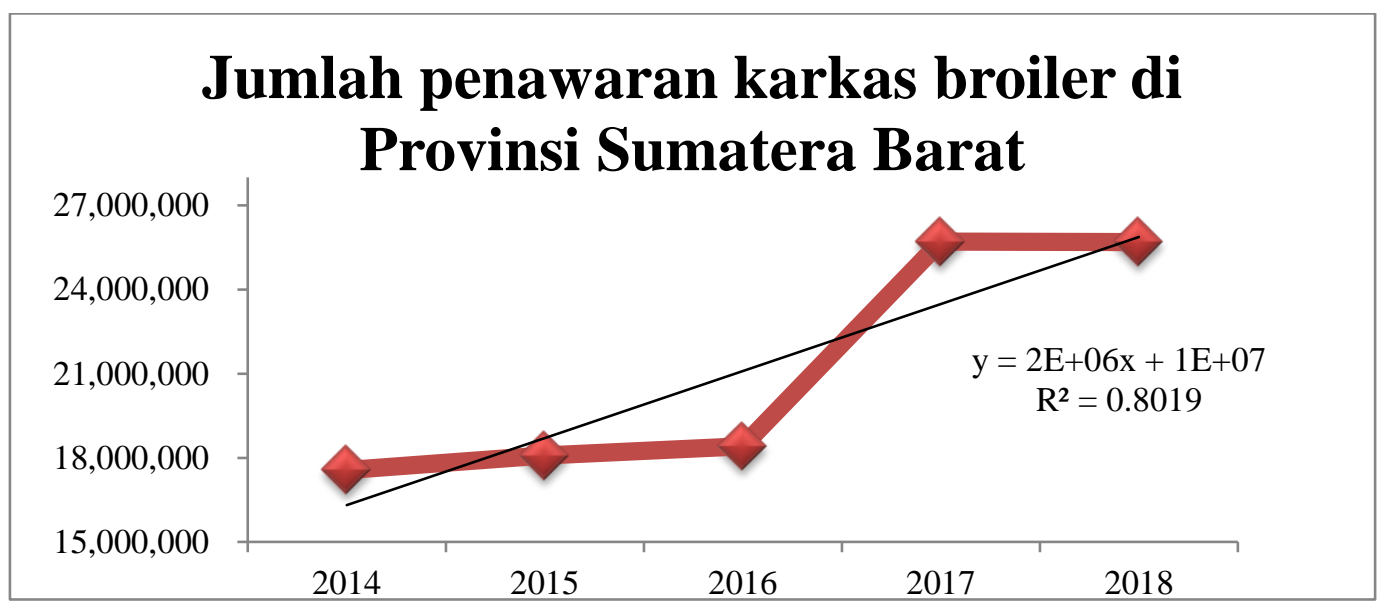

Gambar 2. Grafik jumlah penawaran karkas broiler di Provinsi Sumatera Barat tahun 2014-2018.

Tabel 5 menunjukkan bahwa jumlah penawaran karkas broiler di Provinsi Sumatera Barat tahun 2014-2018 selalu mengalami peningkatan setiap tahunnya. Berdasarkan data tersebut maka dapat diproyeksikan jumlah penawaran karkas broiler dari tahun 2020-2024 dengan menggunakan persamaan linear $\mathrm{Y}=\mathrm{a}+\mathrm{bx}$ atau $\mathrm{Y}=21.091 .830+2.390 .016 \mathrm{X}$ dan proyeksi pada tahun 2019 sebesar 28.261.878 kg, maka dari persamaan linear tersebut dapat diproyeksikan jumlah penawaran broiler di Provinsi Sumatera Barat tahun 2020-2024 seperti pada Tabel 6. 
Tabel 6. Proyeksi penawaran karkas broiler di Provinsi Sumatera Barat tahun 2020-2024.

\begin{tabular}{cc}
\hline Tahun & Penawaran karkas broiler $(\mathbf{k g})$ \\
\hline 2020 & 30.651 .894 \\
2021 & 33.041 .910 \\
2022 & 35.431 .926 \\
2023 & 37.821 .942 \\
2024 & 40.211 .958 \\
\hline
\end{tabular}

Ket: Menggunakan rumus persamaan regresi linear $(\mathrm{Y}=\mathrm{a}+\mathrm{bX})$.

Berdasarkan Tabel 6 proyeksi penawaran karkas broiler di Provinsi Sumatera Barat terus mengalami peningkatan dari tahun ke tahun. Hal ini menunjukkan permintaan broiler akan terus meningkat setiap tahunnya.

\subsection{Peluang pasar}

Setelah permintaan dan penawaran broiler diketahui, maka dapat dihitung peluang pasar dari broiler dengan cara mengurangi jumlah permintaan dan penawaran broiler per tahun. Peluang pasar broiler tahun 2020-2024 terdapat pada Tabel 7.

Tabel 7. Proyeksi peluang pasar broiler di Provinsi Sumatera Barat tahun 2020 2024.

\begin{tabular}{cccc}
\hline Tahun & $\begin{array}{c}\text { Proyeksi } \\
\text { permintaan }(\mathbf{k g})\end{array}$ & $\begin{array}{c}\text { Proyeksi } \\
\text { penawaran }(\mathbf{k g})\end{array}$ & $\begin{array}{c}\text { Peluang pasar } \\
(\mathbf{k g})\end{array}$ \\
\hline 2020 & 33.339 .600 & 30.651 .894 & 2.687 .706 \\
2021 & 35.939 .148 & 33.041 .910 & 2.897 .238 \\
2022 & 38.538 .696 & 35.431 .926 & 3.106 .770 \\
2023 & 41.138 .244 & 37.821 .942 & 3.316 .302 \\
2024 & 43.737 .792 & 40.211 .958 & 3.525 .833 \\
\hline
\end{tabular}


Berdasarkan Tabel 7 bahwa peluang pasar untuk broiler di Provinsi Sumatera Barat tahun 2020-2024 mengalami peningkatan setiap tahunnya. Berdasarkan hal ini sangat memungkinkan untuk berusaha broiler di Provinsi Sumatera Barat.

\subsection{Penjualan}

Produk ini dijual dalam bentuk ayam hidup dan daging segar yang sudah dipotong, dikuliti dan dikeluarkan isi perutnya. Produk dijual langsung di sekitar masyarakat Tanjung Pati.

\subsubsection{Produk}

Produk yang dipasarkan berupa ayam yang sudah disembelih serta dikeluarkan isi jeroannya dan dalam keadaan hidup yang sudah dipelihara sampai umur \pm 28 hari dengan rata-rata bobot badan periode I 1,5 untuk ayam perlakuan dan 1,4 untuk ayam kontrol dan periode II 1,4 untuk perlakuan dan 1,3 untuk kontrol. Daging yang dipasarkan adalah daging halal, karena melalui proses penyemblihan yang sempurna sesuai dengan ajaran agama islam.

\subsubsection{Harga}

Harga produk yang ditawarkan per kg yaitu Rp. 20.000 untuk periode 1 dan Rp. 23.500 untuk periode 2.

\subsubsection{Promosi}

Promosi dilakukan melalui dari mulut ke mulut dan lewat sosial media seperti, Facebook dan Instagram.

\subsubsection{Distribusi}

Distribusi untuk penjualan broiler dilakukan dengan menawarkan langsung kepada masyarakat sekitar Tanjung Pati dan juga bisa dijual langsung di tempat lokasi usaha kepada pedagang pengumpul. 


\section{MATERI DAN METODE PELAKSANAAN}

\subsection{Tempat dan Waktu Pelaksanaan PUM}

Kegiatan Proyek Usaha Mandiri dilaksanakan di kandang broiler UPT Farm Politeknik Pertanian Negeri Payakumbuh pada tanggal 26 Februari 2019 sampai tanggal 14 Mei 2019.

\subsection{Alat dan Bahan}

Alat yang digunakan dalam pelaksanaan pemeliharaan ayam tersebut adalah tempat pakan, tempat minum, piting lampu, bola lampu, ember, tirai plastik, timbangan, kabel, kuas, sapi lidi, pisau, colokan dan ember.

Bahan yang digunakan adalah DOC, BR-1, koran, kapur, sekam padi, vaksin ND, gula, kantong plastik, tali raffia dan tepung daun mengkudu.

\subsection{Data dan Sumber Data}

Teknik pengumpulan data yang tercantum di dalam laporan PUM menggunakan jenis data primer dan sekunder. Data primer merupakan jenis data langsung yaitu berupa data pertambahan bobot badan broiler, konsumsi dan konversi, sedangkan data sekunder diperoleh dari data Dirjen Kesehatan Hewan dan Kementerian Pertanian RI tahun 2018 untuk data di Provinsi Sumatera Barat.

\subsection{Prosedur Pelaksanaan}

\subsubsection{Prosedur pemeliharaan broiler}

Prosedur pemeliharaan broiler yang dilakukan mulai dari persiapan hingga panen adalah sebagai berikut:

\section{Persiapan kandang}

\section{a. Pembersihan kandang}

Sebelum kandang digunakan terlebih dahulu dilakukan sanitasi kandang yaitu dengan cara membersihkan kotoran yang menempel pada kandang, lantai, dinding dan bagian atas kandang dengan cara menyapu, menyiram/menyemprot dan menyikat. Kandang yang telah bersih kemudian didesinfeksi menggunakan rodalon dosis $2 \mathrm{ml} /$ liter air. Kemudian dilakukan pengapuran dengan tujuan untuk 
mencegah dan perkembangan mikroorganisme yang masih tersisa. Cara pengapuran yaitu kapur diencerkan terlebih dahulu dengan air dengan perbandingan $1: 3$, kemudian larutan kapur dioleskan pada permukaan kandang dengan menggunakan kuas.

\section{b. Pembuatan indukan (brooder)}

Pembuatan indukan dibuat dengan bentuk segi empat sebanyak 2 buah. Indukan terbuat dari sekat kayu dengan ukuran 1 x 1 m dengan kapasitas 50 ekor untuk perlakuan dan 50 ekor untuk kontrol. Setiap minggu pemeliharaan dilakukan pelebaran kendang agar tidak terlalu padat yang bisa menyebabkan kematian pada ternak.

\section{c. Penaburan litter}

Litter yang digunakan adalah sekam padi dengan ketebalan $5 \mathrm{~cm}$ dan kemudian dilapisi dengan kertas koran yang bertujuan membuat DOC cepat mengenal pakan dan untuk mencegah agar anak ayam tidak memakan bahan litter. Kertas koran ini digunakan hingga anak ayam berumur dua hari.

\section{d. Tempat pakan dan tempat minum}

Tempat pakan dan tempat minum yang digunakan dicuci terlebih dahulu menggunakan air bersih kemudian direndam dengan desinfektan, yang bertujuan untuk membunuh bakteri atau bibit penyakit.

\section{e. Pemasangan bola lampu}

Kandang dilengkapi dengan 1 buah bola lampu listrik dengan masingmasing 75 watt untuk 50 ekor ayam perlakuan dan kontrol yang berfungsi sebagai pemanas dan penerangan terutama pada malam hari.

\section{f. Pemasangan tirai}

Kandang juga dilengkapi dengan tirai plastik yang dipasang sekeliling kandang untuk menghambat hembusan angin kencang serta masuknya air hujan ke dalam kandang. Pada minggu 1 kandang ditutup rapat dengan tirai. Pada minggu ke II tirai plastik tersebut sudah dapat dibuka 1/3 bagian dan pada minggu berikutnya tirai dibuka seluruhnya sampai masa panen (Rasyaf, 2004). 


\section{g. Persiapan ransum}

Ransum yang diberikan adalah ransum komersil. Ransum komersil diberikan secara ad libitum ditambah dengan tepung daun mengkudu sebanyak $2 \%$ untuk ayam perlakuan. Sedangkan, untuk ayam kontrol pemberian ransum tanpa penambahan tepung daun mengkudu.

\section{Pengadaan DOC}

DOC yang digunakan dalam pemeliharaan kontrol ataupun perlakuan yaitu bibit yang berasal dari PT. Japfa Comfeed Indonesia Tbk yang dibeli dari Poultry Shop di sekitar Payakumbuh. Syarat bibit DOC yang dibeli harus sehat, yaitu DOC tidak cacat, lincah, bulu pusarnya menutup rapi, kakinya bersih dan nampak seperti berminyak, kloaka bersih, bebas dari penyakit, keadaan tubuh normal dan bobot badan sesuai standar yaitu diatas $37 \mathrm{~g}$ (Nastiti, 2014).

\section{Penerimaan DOC}

Sebelum DOC masuk, kebutuhan peralatan kandang dilengkapi seperti tali gantungan tempat pakan dan tempat minum, tirai brooder harus rapat dan mudah dibuka atau ditutup. Tempat pakan, tempat minum dan lampu harus sudah terpasang 2 hari sebelum DOC datang.

Pemanas dinyalakan dan diletakkan di tengah brooder satu jam sebelum DOC datang, agar temperatur brooding sudah cukup stabil saat DOC masuk dan litter sudah menjadi hangat. Pakan dan air minum disiapkan dalam brooder sebelum DOC tiba, air minum yang disediakan adalah air gula sebanyak 2\% (20gram gula pasir per liter air minum).

Pemberian air gula berfungsi untuk mengembalikan stamina DOC yang hilang selama perjalanan dan menghilangkan stres pada DOC. Kemudian diberikan air biasa apabila air gula sudah abis, dan 1 hari pertama pakan diberikan dengan cara menebarkan di atas koran dan di dalam tempat pakan, setelah 1 hari pakan dimasukkan ke dalam tempat pakan. Tempat pakan dan tempat minum ditempatkan secara selang seling sehingga mudah dijangkau oleh ayam dan tidak terlalu dekat dengan pemanas. 


\section{Pemeliharaan broiler}

Pakan yang diberikan pertama kali pada broiler adalah pakan yang dalam bentuk crumble yaitu pakan BR-1, setelah broiler memasuki umur 2 minggu pakan yang diberikan yaitu pakan BR-1 yang dicampur dengan tepung daun mengkudu sebanyak $2 \%$ untuk ayam pedaging yang diberi perlakuan pada periode I sebanyak $1,83 \mathrm{~kg}$ dan periode II $1,97 \mathrm{~kg}$, sedangkan yang kontrol hanya diberi ransum komersil tanpa ada campuran, pemberian pakan secara ad libitum. Pakan yang dihabiskan selama pemeliharaan periode 1 sebanyak 172,47 $\mathrm{kg}$ dan 189,98 $\mathrm{kg}$ untuk periode II.

\section{Pengendalian penyakit}

Broiler sangat rentan terhadap penyakit, oleh karena itu diperlukan pencegahan dan pengendalian penyakit yang baik seperti melakukan sanitasi dan pembersihan kandang setiap hari untuk menjaga kebersihan lingkungan kandang. Selain itu pada umur 4 hari dapat dilakukan vaksinasi. Vaksin merupakan bibit penyakit yang telah dilemahkan yang digunakan untuk mencegah penyakit asal virus atau digunakan untuk merangsang kekebalan tubuh ternak terhadap penyakit tertentu. Vaksin yang digunakan adalah vaksin Medivac ND Lassota yang diberikan melalui tetes mata dan dilakukan pada pagi atau sore hari guna untuk menghindari tingkat stres pada ayam tersebut.

\section{Pengamatan $\mathrm{PBB}$ dan konsumsi ransum perminggu}

Penimbangan pertama dilakukan pada saat DOC datang, selanjutnya penimbangan dilakukan setiap minggu pada seluruh ayam untuk untuk mengetahui pertambahan bobot badan, konsumsi, dan konversi ransum perminggunya baik itu perlakuan maupun kontrol.

\section{Panen}

Panen dilakukan pada ayam berumur 4 minggu dengan bobot hidup untuk periode I 1,5 kg pada perlakuan dan 1,4 kg pada kontrol, sedangkan periode II 1,4 $\mathrm{kg}$ untuk perlakuan dan $1,3 \mathrm{~kg}$ untuk kontrol. Ayam yang dipanen, dijual ke kantor-kantor, rumah makan, ibu-ibu rumah tangga di sekitar Tanjung Pati yang telah disembelih/dipotong serta ke pedagang pengumpul dalam bentuk hidup. 


\subsubsection{Prosedur teknologi}

Teknologi yang digunakan dalam Proyek Usaha Mandiri (PUM) ini adalah pemberian tepung daun mengkudu pada ransum. Jumlah tepung daun mangkudu yang baik diberikan adalah $2 \%$ dari jumlah ransum. Pemberian dilakukan selama 21 hari mulai pada minggu II sampai dengan minggu IV.

Pemberian tepung daun mengkudu dilakukan dengan cara mencampurkan tepung ke dalam ransum dengan memperhatikan standar kebutuhan pakan broiler. Pada minggu kedua hingga minggu ke empat standar pemberian tepung daun mengkudu selalu sama yaitu $2 \%$ dari jumlah standar ransum yang diberikan pada broiler.

Bagan pembuatan tepung daun mengkudu dapat dilihat pada Gambar 3 sebagai berikut:
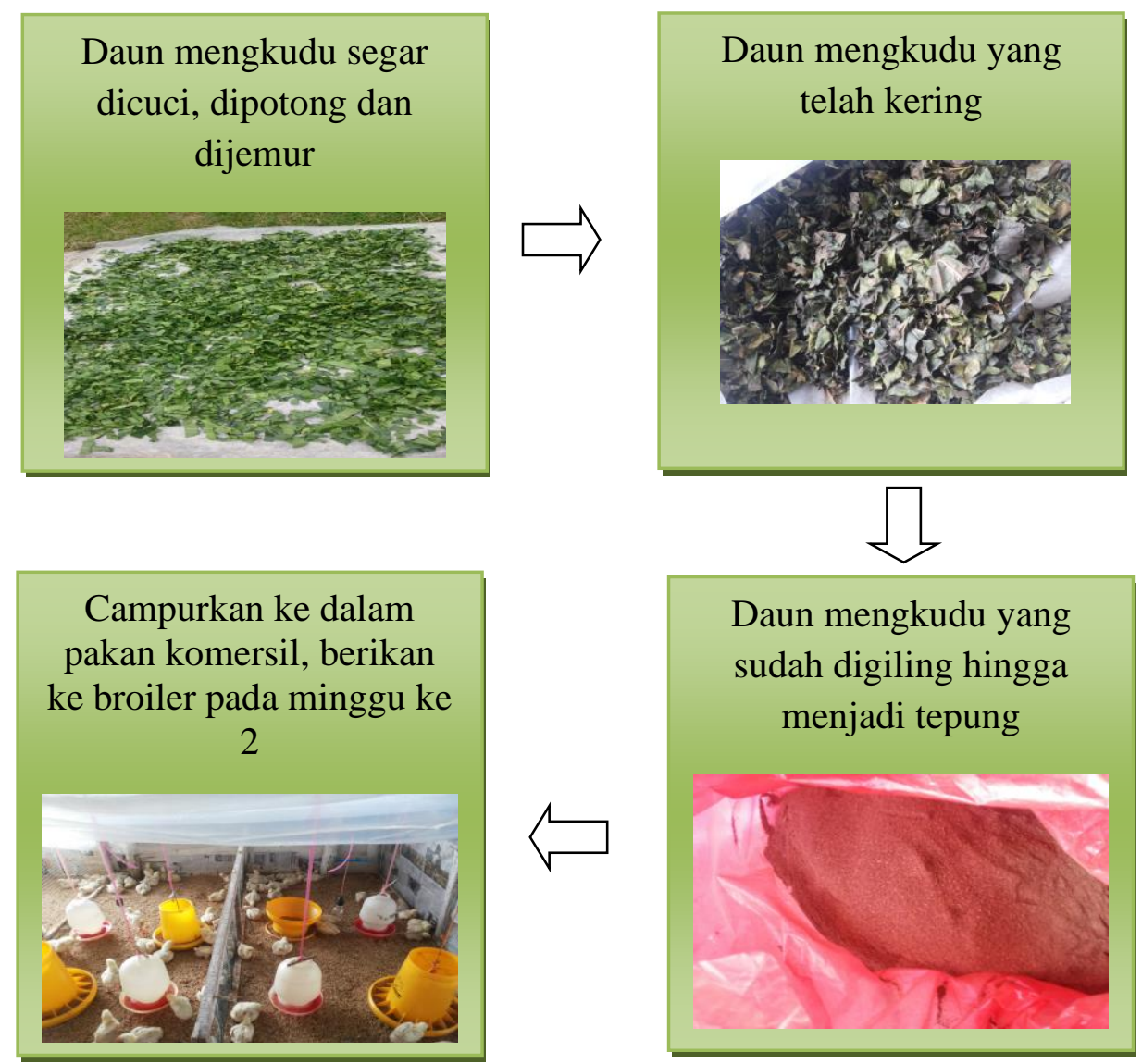

Gambar 3. Bagan pembuatan tepung daun mengkudu. 


\subsection{Variabel yang Diukur atau Diamati}

\subsubsection{Variabel produksi}

\section{A. Pertambahan bobot badan (PBB)}

Pertambahan bobot badan diperoleh dari hasil penimbangan bobot hidup ayam yaitu bobot badan akhir dikurang bobot badan awal.

Pertambahan bobot badan $=$ Bobot badan akhir - Bobot badan awal

\section{B. Konsumsi pakan}

Konsumsi pakan yaitu jumlah pakan yang dikonsumsi/dihabiskan selama pemeliharaan. Untuk mengetahui jumlah konsumsi pakan dapat dihitung dengan rumus :

Konsumsi $=\sum$ Pakan yang diberikan $-\sum$ Sisa pakan

\section{Konversi pakan (FCR)}

Konversi pakan yaitu nilai yang menunjukkan banyaknya ransum yang dihabiskan untuk menghasilkan pertambahan bobot badan dalam satuan waktu tertentu.

$$
\text { Konversi }=\frac{\text { Konsumsi }}{\text { PBB }}
$$

\subsubsection{Variabel finansial}

\section{a. Penerimaan}

Penerimaan merupakan hasil yang didapatkan dari penjualan produk. Penerimaan dapat dihitung dengan rumus :

Penerimaan $=$ Harga jual $\mathrm{x}$ Jumlah produk

\section{b. Biaya}

Biaya adalah pengeluaran yang dikeluarkan selama proses produksi. Biaya terrdiri dari biaya tetap dan biaya variabel. Biaya tetap merupakan biaya yang tidak berubah, ada atau tidak adanya ayam dalam kandang. Sedangkan biaya variabel merupakan biaya yang berhubungan langsung dengan jumlah ayam yang dipelihara. Semakin banyak ayam semakin besar pula biaya variabel, begitupun sebaliknya. 


\section{c. $\quad \mathrm{R} / \mathrm{C}$ ratio}

$\mathrm{R} / \mathrm{C}$ ratio adalah jumlah ratio yang digunakan untuk melihat keuntungan relatif yang akan didapatkan, guna untuk mengetahui perbandingan antara penerimaan penjualan broiler dengan total biaya yang dikeluarkan selam usaha ternak broiler berlangsung. $\mathrm{R} / \mathrm{C}$ dapat dihitung dengan rumus :

$\mathrm{R} / \mathrm{C}=\frac{\text { Penerimaan }}{\text { Biaya }}$

\section{d. Laba}

Laba merupakan tingkat keuntungan yang diperoleh dalam suatu usaha. Laba dapat dihitung dengan rumus :

Laba = Penerimaan - Biaya

\section{e. BEP harga}

BEP harga merupakan seberapa besar harga yang didapatkan untuk memperoleh titik pulang pokok dari produk yang dihasilkan. BEP harga yaitu perbandingan antara biaya yang dikeluarkan dengan total produk.

$$
\text { BEP harga }=\frac{\text { Biaya }}{\text { Hasil }(\mathrm{kg})}
$$

\section{f. BEP produksi}

BEP produksi yaitu berapa banyak produksi yang harus didapatkan untuk memperoleh titik pulang pokok dari harga jual. BEP produksi diperoleh dari perbandingan antara total biaya dengan harga jual produk. BEP produksi dapat dihitung dengan menggunakan rumus :

$$
\mathrm{BEP} \text { produksi }=\frac{\text { Biaya }}{\text { Harga jual }}
$$

\section{g. Persentase keuntungan}

Suatu ukuran dalam persentase untuk menilai suatu usaha broiler apakah mampu menghasilkan laba pada tingkat yang dapat diterima. Persentase keuntungan dihitung dengan menggunakan rumus :

Persentase keuntungan $=\frac{\text { Keuntungan }}{\text { Biaya }} \times 100 \%$

Persentase keuntungan apabila besar dari suku bunga deposito, maka usaha dikatakan layak. Suku bunga yang digunakan adalah suku bunga dari bank BRI yaitu $5,7 \%$ (1 tahun). 


\section{HASIL DAN PEMBAHASAN}

\subsection{Aspek Produksi}

Hasil perencanaan dan realisasi parameter yang diamati dalam proyek usaha mandiri ini terdiri dari pertambahan bobor badan broiler (PBB), konsumsi, dan konversi ransum yang dapat dilihat pada Tabel 8 di bawah ini.

Tabel 8. Pertambahan bobot badan, konsumsi ransum dan konversi ransum selama PUM

\begin{tabular}{llcccccc}
\hline & & \multicolumn{3}{c}{ Perlakuan } & \multicolumn{3}{c}{ Kontrol } \\
\cline { 3 - 8 } No & Uraian & Rencana & Periode I & Periode II & Rencana & Periode I & Periode II \\
\hline 1 & PBB & 1.363 & 1.458 & 1.444 & 1.263 & 1.372 & 1.329 \\
2 & $\begin{array}{l}\text { Konsumsi } \\
\text { ransum }\end{array}$ & 1.669 & 1.998 & 1.968 & 1.700 & 1.982 & 1.866 \\
3 & $\begin{array}{l}\text { Konversi } \\
\text { ransum }\end{array}$ & 1,22 & 1,37 & 1,36 & 1,34 & 1,44 & 1,40
\end{tabular}

\section{A. Pertambahan bobot badan broiler (PBB)}

Berdasarkan data pada Tabel 8, maka dapat dilihat pada grafik pertambahan bobot badan broiler selama PUM pada Grafik 3.

\section{Data pertambahan bobot badan broiler periode 1 dan periode 2}

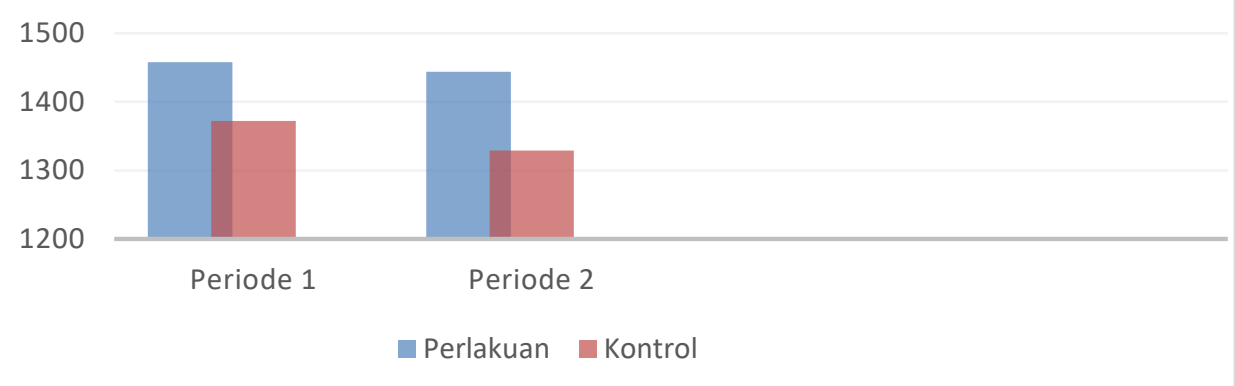

Gambar 4. Grafik pertambahan bobot badan broiler periode 1 dan periode 2.

Tabel 8 dapat menunjukkan bahwa Pertambahan bobot badan perlakuan lebih tinggi jika dibandingkan dengan pertambahan bobot badan kontrol selama 2 kali periode pemeliharaan, karena pakan yang dikonsumsi lebih tinggi. Hal ini sesuai dengan pernyataan Uzer dkk (2013), bahwa pertambahan bobot badan 
broiler berkaitan dengan pakan yang dikonsumsi, apabila konsumsi pakan terganggu maka akan dapat mengganggu pertambahan bobot badan broiler. Selain itu tingginya pertambahan bobot badan broiler perlakuan juga dipengaruhi oleh pemberian tepung daun mengkudu sebanyak $2 \%$ ke dalam pakan komersil. Menurut Wardiny dan Sinar (2011), tepung daun mengkudu mengandung $\beta$ karoten, Fe dan $\mathrm{Zn}$ yang membuat ayam cepat tumbuh. Hal ini sesuai dengan pendapat Piliang (2004), fungsi vitamin A untuk penglihatan dan berperan dalam pertumbuhan serta reproduksi. Mineral Zn penting untuk berfungsinya enzim pancreatic carboxypeptidase A dan B yang mencerna peptida-peptida menjadi asam-asam amino, enzim dipeptidase yang memecah dipeptida menjadi bentuk asam-asam amino bebas dan enzim protease yang memecah protein dalam pencernaan agar dapat diabsorpsi. Adanya peningkatan daya cerna ini mengakibatkan asupan zat-zat makanan menjadi lebih baik sehingga pertambahan bobot badan yang dihasilkan lebih tinggi. Selain itu daun mengkudu dapat membantu penyerapan protein karena adanya senyawa xeronin (Bangun dan Sarwono, 2002).

Pertambahan bobot badan broiler pada periode 1 lebih tinggi dibandingkan dengan pertambahan bobot badan broiler pada periode 2 baik perlakuan maupun kontrol. Hal ini disebabkan karena konsumsi pakan pada periode 1 lebih tinggi dibandingkan dengan konsumsi pakan pada periode 2. Hal ini sesuai dengan pendapat Fajri (2012), bahwa pertumbuhan bobot badan yang cepat didukung dengan konsumsi ransum yang banyak. Sedangkan menurut Abidin (2002), faktor yang mempengaruhi pertambahan bobot badan diantaranya yaitu konsumsi pakan. Selain itu Hidyatullah dkk (2014), juga menyatakan bahwa faktor yang memepengaruhi pertambahan bobot badan adalah jumlah ransum yang dikonsumsi dan kandungan zat makanan dalam ransum.

Pertambahan bobot badan broiler pada realisasi PUM periode 1 dan periode 2, baik perlakuan maupun kontrol lebih tinggi dibandingkan dengan pertambahan bobot badan perencanaan, hal ini disebabkan karena perbedaan bobot awal pada perencanaan dan realisasi. Bobot awal pada perencanaan yaitu 37-gram baik perlakuan maupun kontrol, sedangkan bobot awal pada realisasi periode 1 perlakuan dan kontrol adalah 43-gram dan 42 gram, periode 2 adalah 
40-gram dan 39 gram. Hal ini sesuai dengan pendapat Sklan dan Noy (2001), melaporkan bahwa anak ayam yang lebih berat pada saat menetas akan mencapai berat akhir yang lebih tinggi dibanding anak ayam dengan berat tetas yang lebih ringan, peningkatan berat akhir rata-rata sebesar 8 - 13 g setiap peningkatan sebesar $1 \mathrm{~g}$ dari berat tetas. Sedangkan menurut Vargas dkk (2009), pertambahan bobot badan dipengaruhi oleh bobot awal ayam, semakin tinggi bobot awal, maka semakin tinggi pula pertambahan bobot badan ayam dan kebutuhan ransum juga lebih akan lebih banyak.

\section{B. Konsumsi ransum}

Berdasarkan data pada tabel 8, maka dapat dilihat konsumsi ransum broiler selama PUM pada Grafik 4.

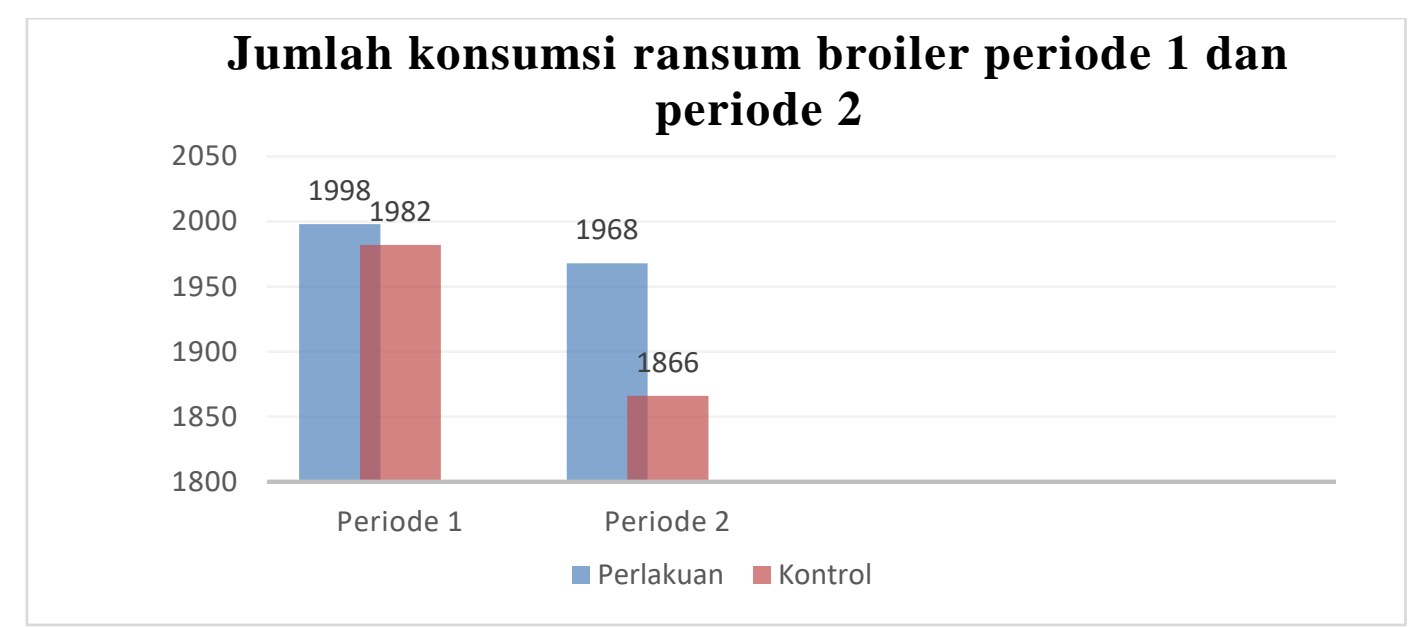

Gambar 5. Grafik konsumsi ransum broiler periode 1 dan periode 2.

Berdasarkan pada Tabel 8 dapat dilihat bahwa jumlah konsumsi ransum broiler pada periode 1 dan periode 2 perlakuan lebih tinggi dibanding yang kontrol. Hal ini disebabkan karena adanya kandungan xeronin di dalam tepung daun mengkudu yang ditambahkan ke dalam pakan perlakuan. Daun mengkudu yang mengandung xeronin, dikenal dapat membantu penyerapan protein (Bangun dan Sarwono, 2002). Senyawa xeronin yang terkandung di dalam tepung daun mengkudu dapat membantu penyerapan protein dalam sistem pencernaan broiler sehingga protein yang dihasilkan akan lebih cepat diserap oleh tubuh. Senyawa xeronin mengandung enzim yang disebut enzim proxeronase dan suatu alkaloid proxeronin, enzim ini di dalam dinding usus besar akan membentuk suatu zat yang aktif yang disebut xeronin. Xeronin ini kemudian akan masuk ke dalam 
aliran darah menuju semua sel tubuh. Semua sel tubuh yang dimasuki xeronin akan menjadi aktif, lebih sehat dan terjadi perbaikan struktur maupun fungsinya. Cepatnya proses penyerapan protein di dalam sistem pencernaan menyebabkan menigkatnya konsumsi broiler. Hal ini disebabkan habisnya cadangan dalam saluran pencernaan yang menimbulkan rasa lapar pada broiler (Solomon, 2002).

Selain itu, tingginya jumlah konsumsi perlakuan disebabkan karena adanya kandungan senyawa alkaloid, saponin, flavonoid, terpenoid dan antrakuinon, serta polifenol pada daun mengkudu (Risna, 2012). Hal ini sesuai dengan pendapat Fajri (2012), yang menyatakan bahwa setiap tanaman yang memiliki kandungan senyawa aktif seperti minyak atsiri, sapoin, flavonoid, dan tannin dapat meningkatkan kecernaan zat makanan di dalam saluran pencernaan sehingga zat makanan yang dikonsumsi dapat diserap dan dimanfaatkan secara optimal untuk pembentukan jaringan tubuh produksi dan reproduksi. Hal ini yang menyebabkan peningkatan konsumsi ransum ayam broiler selama pemeliharaan. Konsumsi sangat berpengaruh terhadap produksi yang dicapai, karena bila nafsu makan menurun, dapat menyebabkan tidak terpenuhinya kebutuhan hidup, sehingga laju pertumbuhan jadi terhambat dan akhirnya produksi akan menurun (Malvin, 2014).

Konsumsi ransum pada saat realisasi selama PUM lebih tinggi dari pada konsumsi ransum yang direncanakan berdasarkan standar kebutuhan broiler yang ada pada literatur baik untuk kontrol maupun perlakuan selama 2 kali periode pemeliharaan, hal ini disebabkan karena pemberian tepung daun mengkudu pada perlakuan, ayam mengkonsumsi ransum lebih tinggi dan tidak mengurangi palatabilitas ternak terhadap ransum yang diberikan, sehingga pertambahan bobot badan broiler yang dihasilkan pada realisasi lebih tinggi dibandingkan dengan pertambahan bobot badan broiler pada perencanaan. Hal ini sesuai dengan pendapat Hidyatullah dkk (2014), menyatakan bahwa faktor yang memepengaruhi pertambahan bobot badan adalah jumlah ransum yang dikonsumsi dan kandungan zat makanan yang ada dalam ransum. Sedangkan menurut Suprijatna dkk (2005), jumlah konsumsi pakan yang lebih banyak akan menghasilkan pertambahan bobot badan lebih tinggi pula. 


\section{Konversi ransum}

Berdasarkan data pada tabel 8, maka dapat dilihat konsumsi ransum broiler selama PUM pada Grafik 4.

\section{Jumlah konversi ransum broiler periode 1 dan periode 2}

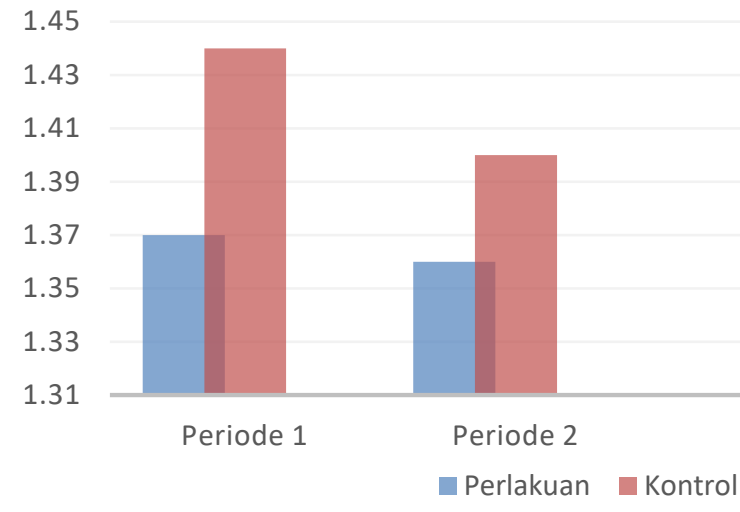

Gambar 6. Grafik jumlah konversi ransum broiler periode 1 dan periode 2.

Tabel 8 menunjukkan bahwa nilai konversi ransum perlakuan lebih rendah dibandingkan dengan nilai konversi ransum kontrol selama pemeliharaan 2 kali periode. Hal ini disebabkan karena pemberian tepung daun mengkudu sampai dengan level $2 \%$ dalam ransum dapat memberikan pertambahan bobot badan yang tinggi (Wardiny dan Sinar 2011). Selain itu dapat juga disebabkan oleh adanya kandungan saponin yang ada pada daun mengkudu. Hal ini sesuai dengan pendapat Risna (2012), bahwa pada daun mengkudu terkandung senyawa alkaloid, saponin, flavonoid, terpenoid dan antrakuinon, serta polifenol. Pemberian saponin dapat meningkatkan permeabilitas dinding sel pada usus dan meningkatkan penyerapan zat makanan, sehingga nilai konversi ransum yang dihasilkan lebih baik (Onning dkk, 1996). Dengan demikian maka nilai konversi ransum akan semakin kecil sehingga penggunaan tepung daun mengkudu efektif terhadap ransum.

Nilai konversi pakan yang rendah berarti semakin efesien pakan yang diberikan (Fati dkk, 2012). Konversi ransum yang didapatkan pada saat pemeliharaan broiler selama PUM untuk periode 2 lebih rendah dibandingkan dengan konversi yang didapatkan pada periode 1. Hal ini disebabkan karena perbedaan jumlah ransum yang dikonsumsi dan pertambahan bobot badan broiler 
yang dihasilkan. Hal ini sesuai dengan pendapat Zuidhof dkk (2014), nilai konversi ransum dipengaruhi oleh jumlah konsumsi ransum dan pertambahan bobot badan. Sedangkan menurut Wijayanti (2011), tinggi rendahnya angka konversi ransum disebabkan oleh adanya selisih yang semakin besar atau kecil pada perbandingan antara ransum yang dikonsumsi dengan pertambahan bobot badan yang dicapai.

\subsection{Aspek Finansial}

Aspek finansial adalah suatu pertimbangan dalam usaha layak atau tidak layaknya pemeliharaan broiler, jika menguntungkan maka usaha broiler layak untuk dikembangkan atau untuk dilanjutkan, analisa finansial dapat dilihat dari hasil penerimaan dan keuntungan, analisa $\mathrm{R} / \mathrm{C}$ ratio, BEP harga, BEP produksi dan persentase keuntungan. Analisa finansial dari pemeliharaan broiler selama 2 kali periode pada pelaksanaan PUM dapat dilihat pada Tabel 9.

Tabel 9. Analisa biaya dan pendapatan

\begin{tabular}{|c|c|c|c|c|c|c|}
\hline \multirow{2}{*}{ Uraian } & \multirow[b]{2}{*}{ Rencana } & \multicolumn{2}{|c|}{ Perlakuan } & \multirow[b]{2}{*}{ Rencana } & \multicolumn{2}{|c|}{ Kontrol } \\
\hline & & Periode 1 & Periode 2 & & Periode 1 & Periode 2 \\
\hline Penerimaan & 1.577 .800 & 1.380 .920 & 1.743 .700 & 1.465 .100 & 1.131 .200 & 1.575 .252 \\
\hline $\begin{array}{l}\text { Rekapitulasi } \\
\text { biaya (Rp) }\end{array}$ & 1.254 .166 & 1.333 .772 & 1.378 .892 & 1.247 .136 & 1.211 .022 & 1.302 .402 \\
\hline Laba (Rp) & 323.634 & 47.148 & 364.808 & 217.864 & $(79.822)$ & 272.850 \\
\hline R/C Ratio & 1,26 & 1,03 & 1,26 & 1,17 & 0,93 & 1,21 \\
\hline $\begin{array}{l}\text { BEP harga } \\
\text { (Rp) }\end{array}$ & 18.282 & 19.317 & 18.583 & 19.578 & 21.411 & 19.429 \\
\hline $\begin{array}{l}\text { BEP hasil } \\
(\mathrm{kg})\end{array}$ & 54,53 & 66,7 & 58,68 & 54,22 & 60,55 & 55,42 \\
\hline $\begin{array}{l}\text { Persentase } \\
\text { keuntungan }\end{array}$ & 25,80 & 3,53 & 26,46 & 17,47 & $-6,59$ & 20,95 \\
\hline
\end{tabular}

\section{A. Penerimaan dan keuntungan}

Berdasarkan pada Tabel 9 untuk pelaksanaan PUM broiler selama 2 kali periode dapat dilihat bahwa perencanaan penerimaan untuk perlakuan yaitu Rp. 1.577.800, dan penerimaan yang didapatkan dari realisasi PUM untuk perlakuan periode 1 lebih rendah daripada periode 2 yaitu Rp. 1.380 .920 dan untuk periode 2 penerimaan perlakuan yang diperoleh yaitu Rp. 1.743.700. Sedangkan untuk 
kontrol penerimaan yang direncanakan yaitu Rp. 1.465.100, dan hasil yang diperoleh dari realisasi PUM untuk kontrol periode 1 yaitu Rp. 1.131.200, lebih rendah dari penerimaan kontrol periode 2 yaitu Rp. 1.575.252. Dari angka tersebut dapat dilihat bahwa penerimaan yang lebih besar diperoleh pada pemeliharaan periode 2 baik untuk perlakuan maupun kontrol. Hal ini disebabkan karena pada periode 1 tingkat kematian lebih tinggi dari pada periode 2 . Banyaknya tingkat kematian ayam pada periode 1 disebabkan karena kurang memperhatikan ventilasi udara dalam kendang sehingga amoniak menjadi tinggi. Hal ini sesuai dengan pendapat Fairchild dan Lacy (2006), bahwa peranan dari sistem ventilasi pada pemeliharaan ayam broiler yakni untuk mengurangi jumlah amoniak yang bisa mengganggu produksi, aspek penyakit sangat dominan sebagai pemicu kematian utama ayam broiler. Tingkat kematian perlakuan lebih rendah dibandingkan dengan kontrol, hal ini disebabkan karena pada daun mengkudu terdapat senyawa antrakuinon yang berfungsi sebagai antiseptik. Hal ini sesuai dengan pendapat Apriyantono dan Farid (2002), bahwa daun dan akar mengkudu mengandung senyawa antrakuinon (damnakantal) yang berfungsi sebagai antiseptik, antibakteri dan antikanker.

Dilihat dari tingkat keuntungan yang diperoleh dari hasil realisasi PUM untuk periode 1 mendapatkan keuntungan pada perlakuan sebesar Rp. 47.148 dan kerugian pada kontrol sebesar Rp. 79.822, hal ini disebabkan karena tingkat kematian yang tinggi, produksi yang rendah dan ditambah karena harga jual yang juga rendah. Sedangkan untuk periode 2 memperoleh laba sebesar Rp. 364.808 untuk perlakuan dan Rp. 272.850 untuk kontrol. Keuntungan yang didapatkan pada periode 2 disebabkan karena harga jual yang lebih tinggi daripada periode 1 dan juga tingkat kematian pada periode 2 juga lebih rendah sehingga dapat meningkatkan hasil produksi untuk perlakuan dan kontrol.

\section{B. R/C ratio}

$\mathrm{R} / \mathrm{C}$ ratio merupakan parameter yang digunakan untuk melihat apakah usaha yang dijalani mengalami keuntungan atau tidak. R/C ratio yang direncanakan untuk pelaksanaan PUM yaitu 1,26 untuk perlakuan dan 1,17 untuk kontrol. Realisasi R/C ratio yang didapatkan pada periode 1 untuk perlakuan yaitu 1,03 dan 0,93 untuk kontrol. Hal ini disebabkan karena hasil dari realisasi 
pelaksanaan pada periode 1 mengalami kerugian pada kontrol. Sedangkan untuk periode $2 \mathrm{R} / \mathrm{C}$ ratio yang didapatkan lebih tinggi daripada periode 1, yaitu 1,26 untuk perlakuan dan 1,21 untuk kontrol, yang artinya setiap pengeluaran biaya Rp. 1000 akan memperoleh pendapatan sebesar Rp. 1.260 dan Rp. 1.210.

\section{BEP harga}

BEP harga yaitu titik pulang pokok dari produk yang dihasilkan. BEP harga yang direncanakan untuk pelaksanaan PUM yaitu Rp. 18.282 untuk perlakuan dan Rp. 19.578 untuk kontrol. BEP harga yang didapatkan dari hasil realisasi pemeliharaan broiler selama PUM untuk periode 1 yaitu Rp. 19.317 untuk perlakuan dan Rp. 21.411 untuk kontrol, sedangkan pada periode 2 BEP harga yang didapatkan yaitu sebesar Rp. 18.583 untuk perlakuan dan Rp. 19.429 untuk kontrol. BEP harga perlakuan lebih rendah dibandingkan dengan BEP harga kontrol karena hasil produksi perlakuan lebih tinggi dibandingkan dengan hasil produksi kontrol.

\section{BEP produksi (hasil)}

BEP hasil merupakan titik pulang pokok dari harga jual produk. BEP produksi yang diperoleh dari hasil realisasi pemeliharaan broiler selama PUM untuk periode 1 yaitu $66,7 \mathrm{~kg}$ untuk perlakuan dan $60,55 \mathrm{~kg}$ untuk kontrol, sedangkan pada periode 2 BEP produksi yang didapatkan yaitu 58,68 kg untuk perlakuan dan 55,42 kg untuk kontrol. Hal ini berbeda dengan BEP produksi yang direncanakan baik untuk perlakuan dan kontrol, dimana BEP produksi yang direncanakan yaitu 54,53 kg untuk perlakuan dan 54,22 kg untuk kontrol.

\section{E. Persentase keuntungan}

Persentase keuntungan yang didapatkan dari hasil realisasi pemeliharaan selama PUM untuk periode 1 yaitu 3,53\% untuk perlakuan dan $-6,59 \%$ untuk kontrol. Persentase keuntungan periode 2 26,46\% untuk perlakuan dan 20,95\% untuk kontrol. Persentase keuntungan usaha dikatakan untung apabila tingkat keuntungan yang diperoleh lebih besar dari bunga deposito Bank yaitu sebesar $5,7 \%$ per tahun. 


\section{KESIMPULAN DAN SARAN}

\subsection{Kesimpulan}

1. Pertambahan bobot badan broiler perlakuan lebih besar dibandingkan dengan kontrol, baik periode 1 maupun periode 2. Periode 1 PBB broiler perlakuan 1.458 g/ekor dan kontrol 1.372 g/ekor, sedangan periode 2 PBB broiler perlakuan $1.444 \mathrm{~g} / \mathrm{ekor}$ dan kontrol $1.329 \mathrm{~g} / \mathrm{ekor}$.

2. Konsumsi ransum broiler perlakuan lebih besar dibandingkan dengan kontrol, baik periode 1 maupun periode 2. Periode 1 konsumsi broiler perlakuan 1.998 g/ekor dan kontrol 1.982 g/ekor, sedangkan periode 2 konsumsi ransum broiler perlakuan 1.968 g/ekor dan kontrol 1.866 g/ekor.

3. Konversi ransum broiler perlakuan lebih rendah dibandingkan dengan kontrol, baik periode 1 maupun periode 2. Periode 1 nilai konversi broiler perlakuan 1,37 dan kontrol 1,44, sedangkan periode 2 nilai konversi ransum broiler perlakuan 1,36 dan kontrol 1,40.

\subsection{Saran}

Bagi peternak yang ingin meningkatkan pertambahan bobot badan broiler disarankan untuk menggunakan tepung daun mengkudu sebagai bahan tambahan dalam pakan dengan taraf pemberian $2 \%$ dari total ransum. 


\section{DAFTAR PUSTAKA}

Abidin, Z. 2002. Meningkatkan produktivitas ayam ras pedaging. Agromedia Pustaka. Jakarta.

Apriyantono, A. dan S. Farid. 2002. Mengkudu (Morinda citrifolia): Efek farmakologis dan teknologi pengolahanya. Saresehan Temu Saran Pengembangan Obat Tradisional Indonesia, Bogor.

Bangun, A.P. dan B. Sarwono. 2002. Sehat dengan ramuan tradisional, khasiat dan manfaat mengkudu. Jakarta : Agromedia Pustaka.

Cahyono, B. 2002. Ayam buras pedaging. Trubus Agriwidya, Semarang

Darusman, L.K. 2002. Mengkudu (Morinda citrifolia) : kandungan bahan aktif dan efek farmakologisnya. Lamongan : Makalah Disampaikan Pada Pertemuan Koordinasi Dalam Rangka Pengembangan Agribisnis Tanam Obat, 25-26 September 2002.

Dirjen Peternakan dan Kesehatan Hewan. Kementrian Pertanian, 2018. Statistik Peternakan dan Kesehatan Hewan. ditjennak.pertanian.go.id (diakses 21 Juni 2019).

Djauhariya, E. dan Tirtoboma. 2001. Mengkudu (Morinda Citrifolia linn) tanaman obat tradisional multikhasiat. Warta Penelitian dan Pengembangan Tanaman Industri Puslitbang Perkebunan Bogor, 7:1-7.

Fairchild, B. dan Lacy, M. 2006. How to control growth to improve economis result. http://www.cobb-vantress. (diakses 25 juni 2019).

Fajri, N. 2012. Pertambahan berat badan, konsumsi dan konversi pakan broiler yang mendapat ransum mengandung berbagai level tepung daun katuk (Sauropus Androgynus). Makalah Hasil Penelitian. Fakultas Perternakan Universitas Hasanuddin Makassar. Makassar.

Fati, N., Syukriani, D. and Malvin, T., 2012. Pengaruh Pemberian Tepung Kangkung Dalam Ransum Terhadap Produksi Dan Kualitas Telur Ayam Arab Petelur. Prosiding. Politeknik Pertanian Negeri Payakumbuh

Fritts, C.A. and P.W. Waldroup. 2003. Evaluation of bBo-Mos ${ }^{\circledR}$ mannanoligosaccharide as a replacement for growth promoting antibiotics in diets for turkeys. Internat. J. Poult. Sci. 2: 19-22.

Hidayatullah, M.F., I.H. Djunaidi dan H. Natsir. 2014. Efek penggunaan tepung limbah roti tawar sebagai pengganti jagung terhadap penampilan produksi itik hibrida. Fakultas Peternakan Universitas Brawijaya.

Kartasudjana dan E. Suprijatna. 2006. Manajemen ternak unggas. Penebar Swadaya. Jakarta.

Malvin, T., 2014. Perbandingan Pemberian Beberapa Level Mikrokapsul Minyak Ikan Dalam Ransum Terhadap Performa Broiler. J. Agrotropical, Vol 4. No 2, https://doi.org/10.31227/osf.io/6rmxg 
Mardiansyah, A. 2013. Performa produksi dan organ dalam puyuh diberi pakan mengandung dedak gandung dan tepung daun mengkudu. Institut Pertanian Bogor, Bogor.

Murtidjo, B.A. 1987. Pedoman bertenak ayam broiler. Yokyakarta, Kanisius.

Nadzir, A., Tusi, A. Haryanto. 2015. Evaluasi desain kandang ayam broiler di desa Rejobinangun, Kecamatan Raman Utara, Kabupaten Lampung Timur. Jurnal Teknik Pertanian Lampung 4(4):255-266.

Nastiti, R. 2014. Menjadi milyarder ayam broiler. Seri Peternakan Ayam Broiler. Jakarta.

National Research Council (NRC). 1994. Nutrient Requirement of Poultry. National Academy Press. Washington, D.C.

North, M.O. dan D.D. Bell. 1990. Commercial chicken production manual.4 Ed an Avian Book, Published by Van Nastrand Rienhard. New York.

Onning, G., Q. Wang, B.R. Westrom, N.G. Asp and B.W. Karlsson. (1996). Influence of oat saponin on intestinal permeability in vitro and in vivo in the rat. Jurnal Nutr, 76, 141-151

Piliang,W.G. (2004). Nutrisi Vitamin Vol. I. Bogor: Pusat Antar Universitas Ilmu Hayati, Institut Pertanian Bogor.

Rail, R. 2007. Tumbuh kembang bagian-bagian karkas ayam broiler pada jenis kelamin dan tingkat umur yang berbeda. Skripsi Fakultas Peternakan, Universitas Haluoleo, Kendari.

Rasidi. 2002. 302 Formulasi Pakan Lokal Alternatif untuk Unggas. Penebar Swadaya. Jakarta

Rasyaf, M. 2003. Berternak ayam pedaging. P.T Swadaya Jakarta. Jakarta.

2004. Beternak ayam pedaging. Penebar Swadaya. Jakarta.

Risna, Y.K. 2012. Pengaruh pemberian tepung daun dan tepung buah mengkudu (morinda citrifolia) dalam ransum terhadap kadar kolesterol daging itik. fakultas pertanian. Universitas Almuslim. Aceh.

Ruhyat dan E. Suprijatna. 2006. Manajemen ternak unggas. Penebar Swadaya. Jakarta.

Sjabana, D. dan R.R. Bahalwan. 2000. Seri Referensi Herbal : pesona tradisional dan ilmiah buah mengkudu (Morinda citrifolia liin). Selemba Medika. Jakarta.

Sklan, D. and Y. Noy. 2000. Hydrolysis and absorption in the small intestines of postshatch chicks. Poult. Sci. 79:1306-1310

Sofyan, O. 2008. Cara meningkatkan budidaya ayam ras pedaging (broiler). Fakultas Peternakan Universitas Brawijaya. Malang.

Solomon, N. 2002. Nutricional content liquid island ofnoni (morinda citrifolia) http://www.javanony.com/id/html (akses tanggal 18 juni 2019). 
Subkhie, H., Suryahadi dan A. Saleh. 2012. Analisis kelayakan usaha peternakan ayam pedaging dengan pola kemitraan di Kecamatan Ciampea Kabupaten Bogor. Manajemen IKM 7(1):54-63.

Suprijatna, E.U, Atmomarsono, R., Kartasudjana. 2005. Ilmu Dasar Ternak Unggas. Penebar Swadaya, Jakarta.

Suprijatna, E. 2008. Ilmu dasar ternak unggas. Penebar Swadaya. Jakarta.

Syamsuhidayat, S.S dan J.R. Hutapea. 1991. Inventaris tanaman obat Indonesia. Badan Litbang Kesehatan, Depkes RI, Jakarta.

Uzer, F., N. Iriyanti dan Roesdiyanto. 2013. Penggunaan pakan fungsional dalam ransum terhadap konsumsi pakan dan pertambahan bobot badan ayam broiler. J. Ilmiah Peternakan. 1 (1): 282-288.

Vargas, F.S. C., T. R. Baratto, F. R. Magalhães, A. Maiorka and E. Santin. 2009. Influences of breeder age and fasting after hatching on the performance of broilers. Poult. Sci. $18: 8-14$.

Wardiny, T.M. 2006. Kandungan kolesterol dan vitamin A telur ayam yang diberi mengkudu (Morinda Citrifolia) dalam ransum ayam ras petelur. Tesis yang tidak dipublikasikan. Fakultas Pasca Sarjana IPB, Bogor.

Wardiny, T.M. dan T.E.A. Sinar. 2011. Substitusi tepung daun mengkudu dalam ransum meninkatkan kinerja ayam broiler. Fakultas Biologi. Universitas Terbuka. Tangerang.

Wijayanti, R.P. 2011. Pengaruh suhu kandang yang berbeda terhadap performans ayam pedaging periode starter. Jurnal Penelitian.Fakultas Peternakan. Universitas Brawijaya. Malang.

Yuwanta dan S.U. Tri. 2004. Dasar ternak unggas. Yogyakarta : Kanisius.

Zuidhof, M.J., B.L. Scheider, V.L. Carney, D.R. Korver and F.E. Robinson. 2014. Growth, efficiency and yield of commercial broilers from 1957, 1978 and 2005. Poult. Sci. 93(12): 29702982.

Zumrotun. 2012. Manajemen brooding pada ayam broiler. Artikel, Berita Dinas. 


\section{Dokumentasi PUM}
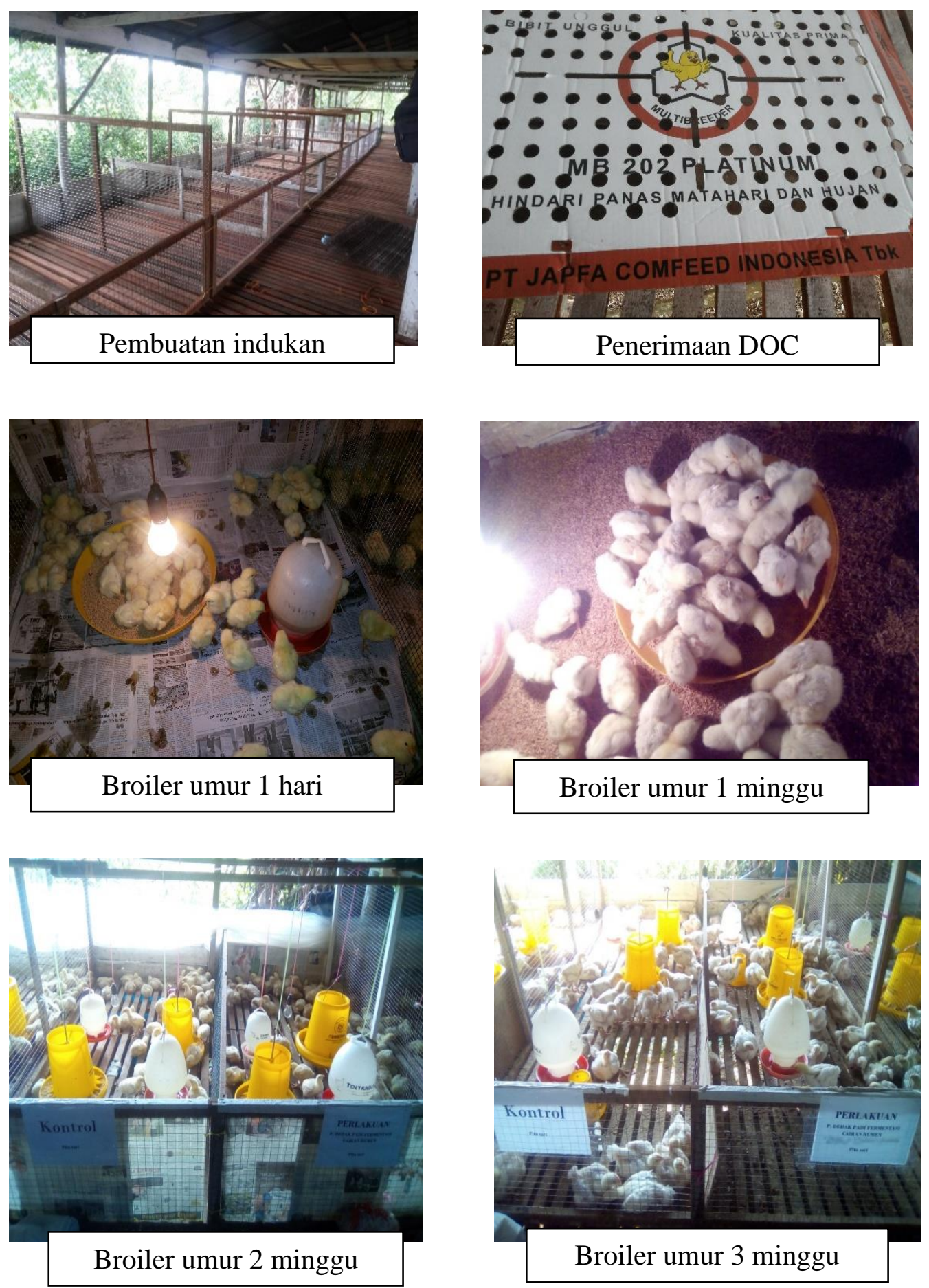

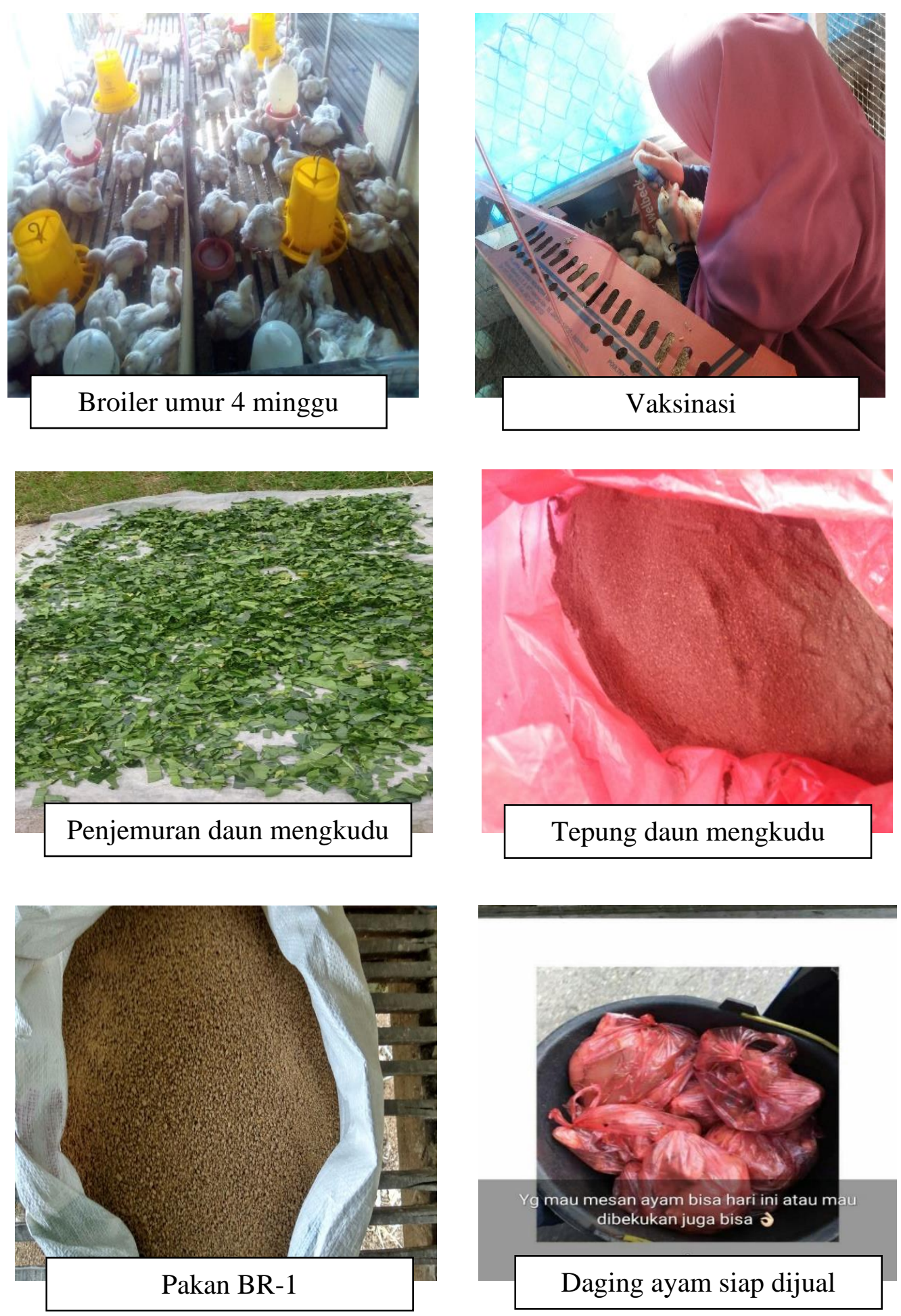